\title{
TURINYS / CONTENTS / СОДЕРЖАНИЕ
}

\section{MIELI SKAITYTOJAI / DEAR READERS / УВAЖAЕМЫЕ ЧИTATEЛИ}

Makarskaitė-Petkevičienė R. „Gamtamokslinis ugdymas“ - naudingas žurnalas pedagogams

Broks A. Systemology and ontodidactics for the development of modern general education

MOKSLINIAI STRAIPSNIAI / SCIENTIFIC ARTICLES / HAУЧНЫE СТATЬИ

Lamanauskas V., Vilkonis R. Fizikos mokymas panaudojant internetą: situacijos analizè ir prognozès

Pečiuliauskienė P., Rimeika A. Būsimụjų gamtamokslinių dalykų mokytojų naudojimasis elektroninèmis mokymo priemonèmis ir informacijos šaltiniais

METODINIAI STRAIPSNIAI / METHODICAL ARTICLES / METOДИЧЕСКИЕ СТАТЬИ

Gervienė O. Dramos metodo panaudojimo galimybès ir realizavimo prielaidos biologijos pamokose

Kučinskienė R. Biologijos tiriamieji darbai Prienu ,Žiburio“ gimnazijoje ir jų reikšmė: moksleivių vertinimai 32

Paškevičienė D., Paškevičius A. Projekto „Mokyklos patalpų oro mikrobiologinės būklès ịvertinimas" metodologiniai aspektai

Vilkonienė M. Gamtamokslinio ir kalbinio ugdymo integravimas panaudojant gamtamokslinès informacijos šaltinius

Красицкий В. А. Школьный химический эксперимент: безопасно, доступно и наглядно 50

\section{INFORMACIJA / INFORMATION / ИНФOРМАЦИЯ}

Informacija autoriams / Instructions for Authors 57

Konferencija „Informacinès komunikacinès technologijos gamtamoksliniame ugdyme“ ___ 58

„, ${ }^{\text {th }}$ European Conference on Research in Chemical Education“" 59 